\title{
SELECTED PROBLEMS OF TERRORIST THREATS TO THE TRANSPORT INFRASTRUCTURE
}

\author{
Gabriel Nowacki \\ Military University of Technology, Cybernetics Faculty \\ Sylwester Kaliski Street 2, 00-908 Warsaw 49, Poland \\ tel.: +48 226839702, fax: +48226837539 \\ e-mail:gnowacki@wat.edu.pl
}

\begin{abstract}
The paper presents problems of terrorism threats for transportation infrastructure. The range of transportation infrastructure has spread, and includes railway, inland waterways, road, maritime, air, intermodal transport infrastructure and intelligent transport systems (ITS). ITS means systems in which information and communication technologies are applied in the field of road transport, including infrastructure, vehicles and users, and in traffic management and mobility management, as well as for interfaces with other modes of transport. ITS application means an operational instrument for the application of ITS. ITS service is the provision of an ITS application through a welldefined organisational and operational framework with the aim of contributing to the user safety, efficiency, comfort and/or to facilitate or support transport and travel operations. Terrorism means acts of violence committed by groups that view themselves as victimized by some notable historical wrong. Although these groups have no formal connection with governments, they usually have the financial and moral backing of sympathetic governments. Typically, they stage unexpected attacks on civilian targets, including transport infrastructure, with the aim of sowing fear and confusion. Based on the analyses, transportation infrastructure is potentially threatened with terrorism attacks, especially road and rail infrastructure (about $23 \%$ ), and to a smaller degree the maritime and air transport infrastructure (about $2 \%$ ). Legal steps to fight terrorism have been taken on the international level; furthermore, some institutions have been established for this purpose at the UN, NATO and UE level as well as Poland too.
\end{abstract}

Keywords: Intelligent transport systems (ITS), transport infrastructure, terrorist threats.

\section{Introduction}

The development of civilisation, scientific and technical progress and new geopolitical situation in the world, cause the forms and means of threat to change.

The most serious danger among new threats to the international system and safety of individual countries, including Poland, creates international organised terrorism and organised crime, although the degree of danger to the individual countries is different. Terrorist attacks are directed at important persons, institutions and countries to cause destruction or panic. Unidentified explosive charges are used for that purpose, are simple homemade or remotely controlled.

More and more real are becoming dangers to Poland in the area of the transport infrastructure, whose aim would be to paralyse the state security system.

Modern transport system must therefore be least susceptible to dangers and durable from the economics, social and environmental protection point of view.

Building future plans of the transport sector development, it is necessary to be aware of it's economic significance. Total expenditure for this sector, about 1000 billion EURO, represents over 10\% EU gross product. It determines development of infrastructure and technology, whose cost to the society is not a subject of questioning. Due to the significance of the expenditures in transport and their particular role in the economic growth, the authors of the Rome Treaty have foreseen creating joint policy, subject to specific regulations.

Transport infrastructure represents a basis for functioning of the economy and it's development should be shaped with a care to the modernity and effectiveness, especially taking into account 
considerable costs of this development. The important reason is ensuring functional and developmental coherence on the mainly European scale.

The main problems in the area of transport in Poland are:

- unsatisfactory state of the road infrastructure,

- insufficient throughput of the main transport routes,

- shortages in the transport interconnections between individual regions,

- low level of road traffic safety,

- shortages in the public transport services,

- low level of intelligent transport systems services (ITS) or their lack.

The transport networks, thanks to the fact that they facilitate the flow of people, freight, increase the possibilities of the trade exchange, affect integration of the domestic markets - make it possible for individual regions to develop.

European program of activities for the road traffic safety defines main areas of actions, and among them better protection of cars by introducing new technical solutions and improving road infrastructure thanks to the application of the intelligent transport systems.

\section{Terminology concerning transport infrastructure}

For the purpose of communicating, especially in professional languages, one often uses dualsegments terms, consisting of the main word and complementary word. Using them together has a purpose of making more precise the meaning of the main word. In the structure of the combined term - „transport infrastructure" the essential determinant, influencing the overall shape of the mental subject, is the word ,infrastructure", while the complementary word describes it's type (character) with the word - ,transport”.

Infrastructure is a group of the essential equipment and institutions, necessary for a correct functioning of the economy and society $[4,17]$.

In view of $\mathrm{W}$. Mirowski, the infrastructure is an international term, meaning a group of essential objects, equipment and institutions of a service character necessary for the correct functioning of the society and production branches of economy [8].

Transport is a transfer of people, freight in space using appropriate means [14]. Transport is closely linked with the remaining branches of economy. It's development is a condition for their development and vice versa - worse economical or transport development is associated with worsening of the situation in respectively transport and economy.

The transport infrastructure is mainly created by the three essential groups:

- routs of all types of transport (road, railway, inland waterways, maritime and air),

- transport junctions (intersections, airports, ports, rail stations, intermodal terminals, logistics centres, etc.),

- auxiliary equipment for the direct servicing of routs and transport junctions.

The term ,transport infrastructure" and it's scope have been defined in the Union legislation and have not changed for a long time, practically since 1970 till 2011. According to the decrees of: the Council nr 1108/70/ECM [11], Commission nr 2598/70/ECM [12] and nr 851/2006/EU [13], the transport infrastructure means all roads and permanent equipment for the three types of transport, which are necessary for ensuring flow and safety of traffic.

The definition and scope of the transport infrastructure will be changed this year, based on the final proposal for a Regulation of the European Parliament and of the Council on Union guidelines (COM 650 final 2011/0294) for the development of the Trans-European Transport Network concerning union guidelines for the development of the trans-European transport network (planned date of acceptance - March 2012).

According to a new decree, the transport infrastructure, including that of trans-European transport network, consists of:

- Railway transport infrastructure, 
- Inland waterways infrastructure,

- Road transport infrastructure,

- Maritime transport infrastructure,

- Air transport infrastructure,

- Multimodal transport infrastructure,

- Equipment and intelligent transport systems associated with the transport infrastructure.

Intelligent transport systems (ITS) mean the systems utilising information, communication, navigational technologies as well as positioning/localising technologies for the purpose of managing mobility and traffic in the trans-European transport network as well as ensuring services of an added value for the citizens and operators, and the use of the network in a safe, protected, ecological and efficient manner as far as throughput is concerned. They can also cover on-board devices, providing that they form inseparable system with appropriate infrastructure elements.

On the 16 of December 2008 European Commission published Announcement - Plan of the introduction of the intelligent transport systems in Europe, COM (2008)886, which found its reflection in the European Parliament's and Council's 2010/40/EU directive [3], M/453 mandate [7] and executive decision EC 2011/453/EU [2].

From the presented analysis of the subject literature, it transpires that the scope of the transport infrastructure will widen, and additionally, in each of the infrastructure category the intelligent transport systems have been highlighted.

\section{The term and essence of the contemporary terrorism}

Terrorism is not a new phenomenon, but is a variable, multi-level and dynamic one, as among the others, the forms, means and objectives of the terrorist activities, change. The terrorism phenomenon is affected by the civilisation development and scientific and technical progress, especially as far as new communication means, mass media and advanced communication technologies are concerned.

The US Defence Department defines the terrorism as unlawful use or the threat of using force or violence against people, property, to pressurise or scare the governments or societies to achieve political, religious or ideological aims [1].

In view of A. Pawłowski [9], the term - terrorism, should be understood solely as the use of violence by the individuals or groups of people, to exert the pressure on both the government and public opinion as well as the groups of people and individual persons.

A. P. Schmidt [15] defined the classic terrorism, as an attack of a subversive forces on the innocent individuals, aimed at causing fear, kill or injure people, and thus force the political concessions from a person or organisation not actually being a direct victim of an assault, and to which the attacked individuals do not belong. This criterion was used in 1988 by Alex Schmid and Albert Jongman. They made a statistical analysis of 109 terrorism definitions [10, 16], and concluded that the most frequently occurring elements are:

- violence/force $-83.5 \%$,

- political aspect of the phenomenon $-65 \%$,

- fear $-51 \%$,

- threats $-47 \%$,

- psychological effect $-41.5 \%$,

- existing discrepancies between the target and victim $-7.5 \%$,

- planned, purposeful, systematic and organised actions $-32 \%$,

- fighting, strategic and tactical methods - 30, 5\%.

According to the UN, the terrorism (Latin) are various ideologically motivated, planned and organised actions of individual people or groups resulting in violating the existing legal order, undertaken for the purpose of forcing the state authorities and society into certain behaviours and 
benefiting actions, often violating the welfare of the outsiders. These actions are performed with an outmost ruthlessness, by various means (physical violence, use of weapons and explosions), in order to give them maximum publicity and intentionally causing fear in the society [21].

According to the criminal code [19], the crime of a terrorist character is a forbidden act punishable by an imprisonment, whose limit is at least 5 years, and which is committed in order to:

- seriously frighten many people,

- force the public authorities of the Republic of Poland, other country or the international organisation authorities, to undertake or abandon certain activities,

- cause serious disturbances in the political system or the economy of the Republic of Poland, other country or the international organisation - as well as the threat of committing such an act.

The main forms of the terrorist attacks are:

- assault against life - is directed most often against important persons, political party leaders,

- bomber attack - exerts specific psychological pressure on the society,

- hijacking vehicle or plane,

- taking hostages, kidnapping - serves the purpose of using them as a trade over element in meeting the demands.

It needs to be noted also that $95 \%$ terrorist attacks in the world were conducted using explosives.

\section{Terrorist attacks conducted on the transport infrastructure objects}

In view of the Aon Global Risk Consulting experts, in 2008 and 2009, the most often targeted trade by the terrorists was retail trade $(24,18 \%)-$ Tab. 1 .

Tab. 1. Terrorist attacks on various trades [20]

\begin{tabular}{|l|c|}
\hline Retail trade, gastronomy. & $24.18 \%$ \\
\hline Land transport (road, railway). & $23.36 \%$ \\
\hline Mining industry. & $14.55 \%$ \\
\hline $\begin{array}{l}\text { Infrastructure (objects of the state authorities, local governments, public, religious } \\
\text { cult). }\end{array}$ & $8.2 \%$ \\
\hline Construction. & $5.74 \%$ \\
\hline Tourism. & $6.56 \%$ \\
\hline Finances. & $2.05 \%$ \\
\hline Air transport. & $2.46 \%$ \\
\hline Maritime transport. & $2.25 \%$ \\
\hline Public utility enterprises. & $2.25 \%$ \\
\hline Other. & $8.4 \%$ \\
\hline Total & $100 \%$ \\
\hline
\end{tabular}

Affected were not only the shopping centres or supermarkets, but also small gastronomy outlets, restaurants, clubs and bars. It is possible to indicate three main reasons for the terrorist attacks in the retail sector. First of all, vast part of them is directed at the shops owned by non-Islamic people. Secondly, the terrorists often chose renowned makes as the target of their attacks, which are a symbol of the western world and capitalism. And thirdly, the retail trade is an attractive target for the attacks of the terrorist groups due to the possibility of causing significant human losses, serious difficulties in the everyday life and an effective scaring of the civilian population.

The second place on the list of the terrorist attacks takes road and railways transport infrastructure $(23,36 \%)$, and the selected terrorist attacks conducted in 1970-2011, are presented in the Tab. 2. 
Tab. 2. Selected terrorist attacks carried out on the transport infrastructure objects

\begin{tabular}{|c|c|c|c|}
\hline No. & Place, date & Type of attack & Victims \\
\hline 1. & Israel, 8 May 1970. & PLO attack on the school bus. & $\begin{array}{l}9 \text { children and } 3 \text { adults died and } \\
19 \text { were injured. }\end{array}$ \\
\hline 2. & $\begin{array}{l}\text { Switzerland - Israel, } \\
21 \text { February } 1970\end{array}$ & $\begin{array}{l}\text { Bomb explosion in on board of the } \\
\text { Swissair } 330 \text { airliner. }\end{array}$ & 47 people died. \\
\hline 3. & $\begin{array}{l}\text { Yugoslavia } 26 \\
\text { January } 1972 .\end{array}$ & $\begin{array}{l}\text { Attack on the DC-9 aircraft of the } \\
\text { Yugoslav airline. }\end{array}$ & $\begin{array}{l}27 \text { people died ( } 23 \text { passengers } \\
\text { and } 4 \text { crewmembers). }\end{array}$ \\
\hline 4. & Israel 30 May 1972 & $\begin{array}{l}\text { Bomb attack at the Lod airport in } \\
\text { Israel, }\end{array}$ & 26 people died, 78 were injured. \\
\hline 5. & India, 23 June 1985 & $\begin{array}{l}\text { Bomb attack on board of the Boeing } \\
747 .\end{array}$ & 329 people died. \\
\hline 6. & $\begin{array}{l}\text { Japan, } 20 \text { March } \\
1995 .\end{array}$ & $\begin{array}{l}\text { Attack on Tokyo underground, using } \\
\text { sarin gas. }\end{array}$ & $\begin{array}{l}13 \text { people died, } 5 \text { thousand were } \\
\text { seriously intoxicated }\end{array}$ \\
\hline 7. & $\begin{array}{l}\text { USA, } 11 \text { September } \\
2001 .\end{array}$ & Attack on WTC and Pentagon. & $\begin{array}{l}2973 \text { people died, } 19 \text { hijackers } \\
\text { and } 26 \text { people were missing }\end{array}$ \\
\hline 8. & $\begin{array}{l}\text { Spain, } 11 \text { March } \\
2004 .\end{array}$ & Bomb attack in Madrid underground. & $\begin{array}{l}191 \text { people died, } 1900 \text { were } \\
\text { injured. }\end{array}$ \\
\hline 9. & $\begin{array}{l}\text { Russia, } 6 \text { February } \\
2004 .\end{array}$ & Bomb attack in Moscow underground. & $\begin{array}{l}41 \text { people died, and over } 100 \\
\text { were injured. }\end{array}$ \\
\hline 10. & $\begin{array}{l}\text { G. Britain, } 7 \text { July } \\
2005 .\end{array}$ & Bomb attack in London underground. & $\begin{array}{l}52 \text { people died, and at lest } 700 \\
\text { were injured. }\end{array}$ \\
\hline 11. & $\begin{array}{l}\text { India, } 19 \text { February } \\
2007 .\end{array}$ & Bomb attack express train. & $\begin{array}{l}68 \text { people died, many were } \\
\text { injured. }\end{array}$ \\
\hline 12. & $\begin{array}{l}\text { Africa, } 8 \text { January } \\
2010 .\end{array}$ & $\begin{array}{l}\text { Coach carrying Togo soccer players to } \\
\text { an African nations Cup machine- } \\
\text { gunned. }\end{array}$ & $\begin{array}{l}\text { At least } 195 \text { people died, about } \\
300 \text { were injured. }\end{array}$ \\
\hline 13. & $\begin{array}{l}\text { Russia, } 29 \text { March } \\
2010 .\end{array}$ & $\begin{array}{l}\text { Bomb attack on underground in the } \\
\text { centre of Moscow, carried out by two } \\
\text { suicide women. }\end{array}$ & $\begin{array}{l}\text { At least } 39 \text { people died, and } 102 \\
\text { were injured }\end{array}$ \\
\hline 14. & $\begin{array}{l}\text { Russia, 24 January } \\
2011 .\end{array}$ & $\begin{array}{l}\text { Bomb attack at the Domodiedowo } \\
\text { airport. }\end{array}$ & $\begin{array}{l}36 \text { people died, and at lest } 180 \\
\text { were injured }\end{array}$ \\
\hline 15. & $\begin{array}{l}\text { Belarus, } 11 \text { April } \\
2011 .\end{array}$ & Bomb attack in Minsk underground. & $\begin{array}{l}15 \text { people died, and } 204 \text { were } \\
\text { injured }\end{array}$ \\
\hline 16. & $\begin{array}{l}\text { Norway, } 22 \text { July } \\
2011 .\end{array}$ & $\begin{array}{l}\text { Attack in Oslo, youths shot on the } \\
\text { Utaja Island. }\end{array}$ & 76 people died. \\
\hline
\end{tabular}

\section{Combating terrorism at the international and national level}

UN has taken many efforts to fight terrorism from 1963 and accepted many conventions. Security Council created Counter-Terrorism Committee Executive Directorate (CTED) based on resolution 1535 from 2004. General Secretary appointed UN Counter-Terrorism Implementation Task Force - CTITF in 2005.

8 September 2006 all UN member states accepted Global Strategy of Combating Terrorism [5]. For the first time in history, a joint stand has been agreed on combating terrorism. Accepting Global Strategy of Combating Terrorism crowns years of efforts and at the same time fulfils the obligation made by the world leaders at the World Summit in September 2005. While developing strategy, many proposals and recommendations presented by a former Secretary General Kofi Annan were taken into account.

The basis for the strategy is unequivocal, unconditional and firm condemnation of terrorism in all it's forms - used by anybody, anywhere and for whatever reasons. The strategy establishes concrete measures that are to be taken in order to eliminate causes for spreading terrorism and to strengthen individual and joint capability of nations and United Nations in preventing and 
combating terrorism, protecting simultaneously human rights and legal rules.

The strategy combines many new proposals and strengthenings of the current actions taken by the member states, system UN and other international and regional institutions into a common platform of strategic co-operation.

The terrorism creates direct danger to the safety of the NATO states and for the international stability and welfare. The terrorist groups infiltrate and propagate in the areas of a strategic significance to the Alliance, modern technology causes increase of the danger and potential threat of the terrorist attacks, especially if the terrorists were to come into possession of the nuclear, chemical, biological or radiological capabilities.

At the NATO, level operates EADRCC (Euro-Atlantic Disaster Response Coordination Centre), created in June 1998, at the NATO Head Quarters, based on the motion put forward by the Russian Federation. Created, as part of the Partnership for Peace program, Centre co-ordinates NATO the partner states' actions in the area of the Euro-Atlantic in a reaction to natural disasters and those caused by a man. All those tasks are conducted in a close co-operation with the UN Office for the Co-ordination of Humanitarian Aid (UN OCHA), which has been entrusted with a superior role in co-ordinating international actions during disasters. Since 2001, EADRCC has played a role in co-ordinating the reaction of the countries to a terrorist attacks with the use of chemical, biological or radiological weapons, as well as the activities managing the consequences of those events.

The Military Concept for Defence against Terrorism and the Partnership Action Plan Against Terrorism were taken in Prague Summit in 2002. The Terrorist Threat Intelligence Unit - (TTIU) was created in Istanbul Summit in 2004.

In accordance with a strategic concept of defence and safety of the members of the NATO treaty, the Alliance is takes on itself obligation to prevent crises, terrorist threats, managing conflicts and stabilising post-conflict situations, including closer co-operation with international partners, especially United Nations Organisation and European Union.

The European Council on the 25 march 2004 accepted the Declaration and a Plan, being an annex to the Declaration, on combating terrorism. One of the most important provisions is acceptance of, so called, solidarity cause. It envisages, that in case of the terrorist attack on any EU member state, all remaining members will mobilise every available means, they regard as appropriate (including military ones), to help the state in trouble. In the declaration, there is a reference also to the European Security Strategy of December 2003, in which the terrorism was regarded as one of the most serious dangers to the international security.

At the EU level there has been Monitoring and Information Centre (MIC) established, which is available and capable of an immediate reaction, 24 hours a day, and also serving the member states and the European Commission to react to dangers. The Centre serves 31 states (27 EU states and Croatia, Lichtenstein, Iceland and Norway).

More over, the Common Emergency Communication and Information System (CECIS) is used in the Crises Situations in order to enable the communication between MIC and the contact points in the member states as well as sharing by them the information and managing them.

The Schengen zone countries use Schengen Information System - SIS, and the access to the system is in the possession of the police, consular offices and Border Guard together with Customs Offices and it enables the verification of people during the border control as well as during the control within the country.

The Counter-Terrorism Coordinator (CTC), the Counter Terrorism Group (CTG) and the Joint Situation Centre (SITCEN) were appointed to fight terrorism in the European Union.

At the EU level, there have been independent institutions: Europol, Eurojust and Frontex.

Europol (European Police Office) is the European Union law enforcement agency that handles the exchange and analysis of criminal intelligence in preventing terrorism and serious international crime in order to raise the safety within the entire Europe. Europol commenced its full activities on 1 July 1999. 
Eurojust (The European Union's Judicial Cooperation Unit ) is body established in 2002 to stimulate and improve the co-ordination of investigations and prosecutions among the competent judicial authorities of the European Union Member States when they deal with serious crossborder and organized crime.

Frontex (French: Frontières extérieures) is European Agency for the Management of Operational Cooperation at the External Borders of the Member States of the European Union. Frontex started to be operational on October 3, 2005 is headquartered in Warsaw.

On the wide international forum there has been INTERPOL used (188 countries) - the police organisation in the EU countries and from outside the Union, e.g. Belarus, Russia, Ukraine. The co-operation takes place as part of the liaison officers network of the Polish Police operating in such EU countries as France, Holland, Germany, Great Britain, and countries outside the Union, i.e. Belarus, Russia, Ukraine. They have a direct access to the police databases (lost and wanted persons, dactyloscopic cards, DNA profiles, stolen vehicles and documents, etc.).

In Poland, combating terrorism is dealt with by the following institutions:

- at the strategic level: Government Centre for Security (GCS), National Crisis Management Team (NCMT), Interdepartmental Team for the Terrorist Threat (ITTT), Internal Security Agency (ISA), Intelligence Agency (IA), Military Intelligence Service (MIS), Military Counter-Intelligence Service (MCIS), Police Head Quarters (PHQ), Border Guard Head Quarters (BGHQ), Chief Inspector for the Financial Information (CIFI), Customs Service (CS), State Fire Service Head Quarters (SFBHQ), Government Protection Bureau (GPB), Military Police Head Quarters (MPHQ), General Staff of the Polish Armed Forces, National Atomic Energy Agency (NAEA), Civil Aviation Authority (CAA), Polish Air Navigation Services Agency (PANSA);

- at the operational level: Anti-Terrorist Centre ([6]. ATC operates in 24 hours system, and is staffed, apart from the ISA, delegated officer, soldiers and the employees of the Police, BG, GPB, IA, MIS, MCIS, CS. They tackle tasks within the institution's competencies they represent. Additionally ATC co-operates actively with other entities participating in the antiterrorist protection system of the Rep. of Poland, such as GCS, Foreign Ministry, State Fire Service, CIFI, General Staff of the Polish Armed Forces, Military Police, etc. The essence of the ATA functioning system is coordination of the information exchange process between the antiterrorist protection system participants, enabling implementation of the common procedures for reacting at the occurrence of one of the four categories of the defined threat:

- terrorist threat occurring outside the Polish boarders but affecting the security of the RP and it's citizens,

- terrorist occurrence taking place on the Polish territory affecting the security of the RP and it's citizens,

- information obtained about a potential threats that may take place on the Polish territory outside the Polish boarders,

- information obtained concerning laundering money or transferring financial resources that may a proof of financing the terrorist activities.

- at the tactical level: special units, services and institutions answering to the Internal Affairs Minister (IAM), National Defence Minister (NDM), Financial Minister (FM), Minister of Transport, Construction and Maritime Economy (MTCME), special units.

Intelligence and counter-intelligence tasks of the special services (ISA, IA, MIS, MCIS) concern recognising and counteracting the internal and external occurrences, which threaten the state's interests. The essential role of the special services relies on obtaining, analysing, processing and conveying to the correct authorities, the information, which can be of considerable significance for the state security in every aspect, as well as on the pre-emptive informing about the potential and existing threats to the country. Special attention is given to preventing and counteracting the terrorism, protecting the defence and economic capabilities of the country, being 
a condition for it's international position. The special services ensure the counterintelligence protection of the country, especially in respect to the functioning of the main elements of the critical infrastructure, including transport networks [18].

The superior objective of the Police actions is serving the society by effectively protecting the security of people and property as well as maintaining security and public order. The Police prevent crime and criminogenic phenomena, including those of a cross-boarder character, cooperating with other guards, services and state inspections as well as the police of other countries together with the international organisations. The Police are prepared also for providing a wider support to missions conducted by other state and none-governmental entities, as well as the Armed Forces of RP. Preventing and effective response to the cases of organised crime should remain the care of not only the Police, but also other services and departments. Polish police should actively participate and initiate solutions at the international institutions of the police co-operation, such as Interpol or Europol, and develop the network of its liaison officers, actively representing Polish police outside the country.

As the priority actions should be regarded the co-operation of the Police law enforcement bodies, Internal Security Agency with the Anti-Terrorist Centre, for the purpose of eliminating the terrorist and criminal events.

The superior objective of the Boarder Guard is an effective protection of the state borders and controlling the boarder traffic in accordance with the interests of the state security interests. It's special role is to protect one of the longest land sections of the external boarder of, both the European Union and NATO, as well as the responsibilities resulting from signing the Schengen Treaty by Poland.

It is necessary to continue and improve co-operation between the Border Guard, the Police and other services. The monitoring and migration control of the foreigners on the entire territory of the country is an important area requiring the intensification of the co-operation of these services, which should also have a preventive character. Both the Police and the Border Guard, as part of the statutory activities, ought to constantly monitor the threats of a terrorist character, co-operating in that, with other services.

The superior objective of the State Fire Service is recognising threats, preparing and carrying out the rescue actions. The SFS possesses the ability to immediately respond in cases of a threat to life and health, environment and property as well as in the cases of the extraordinary threats, disasters and natural disasters.

\section{Conclusions}

The organised international terrorism represents a threat to Europe including Poland. Poland has to take into account the possibility of having to take actions against it in connection with participation in the antiterrorist campaign. It is impossible to rule out retaliatory actions being a consequence of the conducted by NATO or EU stabilising and peace keeping operations [18]. The organised international crime is also a threat to Poland, which is a result of the transit geographical location of Poland and the character and methods of operation of the international criminal groups. Poland's accession to the full realisation of the Schengen Treaty, and what it entails, elimination of the boarder control on the sections of the internal EU border, may result in the reduction of the barriers for the influx of wanted people, impairment of the counteracting the terrorist threat, and also in facilitating the inflow onto the Poland's territory of the waste contaminating the environment and psychoactive substances, from the EU countries, where their possession is allowed.

To ensure high safety standards in the transport sector it is necessary to implement integrated security system, serving both preventing dangerous occurrences, as well as effective mitigating the consequences of such occurrences. The integration of the preventive actions is especially important in case of the transport hubs, representing the areas of co-operation of various branches 
of transport - air and maritime ports and railway stations integrating various transport means. The expansion of the transport networks will affect the improvement the conditions of the people's and equipments relocation, necessary to take actions as part of the state security system. It will also contribute to fulfilling the existential needs of the population, including the possibility of its evacuation and it will also become an important element of supporting RP's Armed Forces and allied forces in case of some crisis or armed conflict.

The EU membership creates development chances for Poland as far as, quick modernisation and building new transport systems, are concerned. Not taking advantage of those chances may cause marginalising the significance of Poland, as a transit country and elimination of the trade exchange possibilities that occur on the Eastern-European market. At the same time the significance and rank of the effectiveness of control and monitoring haulage as well as storing, distribution of the dangerous goods and, so called, dual application materials, with the possibility of them being used for the terrorist purposes, increases.

The terrorist attacks threats to the transport infrastructure are in the world quite significant, and so far, this trade attracted about $24 \%$ of all attacks carried out.

The state services of the $\mathrm{R}$ of $\mathrm{P}$ are well prepared to recognise, prevent and combat terrorist threats. The most important is the co-operation of all services as well as an early recognition of the threat and not allowing the terrorist attack to take place (prevention).

More over, it would be advisable to prepare guidebooks concerning the behaviour of people in the crises situations, especially about the symptoms of the terrorist attack being prepared and the ways the people should behave in such cases.

\section{References}

[1] Aleksandrowicz, T. R., International terrorism, Warsaw 2008.

[2] Commission Implementing Decision 2011/453/EU of 13 July 2011 adopting guidelines for reporting by the Member States under Directive 2010/40/EU of the European Parliament and of the Council (notified under document C2011/4947). OJ of the EU, L 193/48, 49 of 23/7/2011.

[3] Directive 2010/40/EU of the European Parliament and of the Council of 7 July 2010 on the framework for the deployment of Intelligent Transport Systems in the field of road transport and for interfaces with other modes of transport. OJ of EU, L 207 , 06/08/2010 P. 0001 0013.

[4] Encyclopaedia PWN, PWN, Warsaw 1982.

[5] NATO (2010), Strategic Concept for the Defense and Security of The Members of the North Atlantic Treaty Organization, Adopted by Heads of State and Government in Lisbon, http://www.nato.int/lisbon2010/strategic-concept-2010-eng.pdf, 2010.

[6] Makarski, A., Atiterrrosim Center of ABW. Genesis, activities, rules and experiences after one year functioning, Review of Internal Security, No 2, Warsaw, 2010. http://www.abw.gov.pl/portal/pl/273/642/Przeglad_Bezpieczenstwa_Wewnetrznego_nr_2_2 2010.html.

[7] $\bar{M}$ /453 EN. Standardization mandate addressed to CEN, CENELEC and ETSI in the field of information and communication technologies to support the interoperability of co-operative systems for Intelligent Transport in the European Community, DG ENTR/D4, Brussels, 6th October 2009.

[8] Mirowski, W., Study on Polish country infrastructure, The equipment areas of social infrastrycture, T. III, PAN Instytut Rozwoju Wsi i Rolnictwa, Warszawa 1996.

[9] Olechów, B., Terrorism in after bipolar Word. Adam Marszałek, Toruń 2002.

[10] Pawłowski, A., Terrorism in Europeof $X I X \& X X$ century, Lubuski Komitet Upowszechniania Prasy, Zielona Góra 1994. 
[11] Regulation (EEC) No 1108/70 of the Council of 4 June 1970 introducing an accounting system for expenditure on infrastructure in respect of transport by rail, road and inland waterway. OJ L 130, 15.6.1970, pp. 4-14.

[12] Regulation (EEC) No 2598/70 of the Commission of 18 December 1970 specifying the items to be included under the various headings in the forms of accounts shown in Annex I to Council Regulation (EEC) No 1108/70 of 4 June 1970. OJ L 278, 23.12.1970, pp. 1-5.

[13] Commission Regulation (EC) No 851/2006 of 9 June 2006 specifying the items to be included under the various headings in the forms of accounts shown in Annex I to Council Regulation (EEC) No 1108/70. OJ L 158, 10.6.2006, pp. 3-8 .

[14] Rydzkowski, W., Wojewódzka-Król, K. (red.), Transport, PWN, Warszawa 2008.

[15] Schmid, A. P., Political Terrorism: A New Giude to Actors, Authors, Concepts, Data Bases, Theories and Literature, New Brunswich, NJ 1988.

[16] Schmid, A. P., Jongman, A., Political terrorism, SWIDOC, Amsterdam 1988,

[17] Polish language dictionary (Słownik języka polskiego), PWN, Warsaw 1978.

[18] Strategy of National Security for Republic of Poland, Warsaw 2007.

[19] The act from 16 April 2004 on change of the act - Penal Code (Kodeks Karny) and others acts, No. 93, pos. 889, OJ 2004.

[20] The report of Aon Global Risk Consulting, http://forsal.pl/wiadomosci/polska/341600.html; http: //www.aon.com/poland, 2008 and 2009.

[21] The report of UNIC, http://www.unic.un.org.pl/terroryzm/definicje.php, from 10.02.2012. 